\title{
Pendidikan Kesehatan Berbasis Gambar Untuk Pencegahan Kecacingan Bersumber Tanah di Papua Barat
}

\author{
Noviyanti*1, Purwaningsih ${ }^{2}$, Febriza Dwiranti ${ }^{3}$ \\ 1,2Program Studi Kesehatan Hewan, Fakultas Peternakan, Universitas Papua \\ ${ }^{3}$ Program Studi Biologi, Fakultas MIPA, Universitas Papua \\ *e-mail: n.noviyanti@unipa.ac.id ${ }^{1}$, p.purwaningsih@unipa.ac.id², fbrzdwiranti@gmail.com ${ }^{3}$
}

\begin{abstract}
Papua and West Papua provinces are considered as high transmissible areas of Soil-Transmitted Helminthiasis (STH); several studies reported the prevalence level were higher than 50\%. The World Health Organization recommends regular anthelmintic treatment for school-age children supported by improved hygiene behavior. A Community Service team from the University of Papua aimed to educate elementary school-age children and parents on health and hygiene practices by targeting two villages, Desa Sidey Makmur and Desa Kaironi in Sidey District, Manokwari, West Papua. The team created and used picture-based materials such as poster, flipchart and short movies during the service. The team observed that health education by using picture-based and audiovisual materials were easy to understand by the audience who had various educational backgrounds, gender, and age. Hence, picture-based health education is effective to improve health quality in the rural areas in West Papua province.
\end{abstract}

Keywords: Soil-Transmitted Helminthihasis (STH), health behavior, health education, picture-based health education

\section{Abstrak}

Papua dan Papua Barat termasuk daerah yang memiliki angka transmisi tinggi untuk cacing bersumber tanah; beberapa penelitian melaporkan angka prevalensi lebih besar dari 50\%. Organisasi Kesehatan Dunia menyarankan pemberian obat cacing rutin untuk anak usia sekolah yang didukung dengan peningkatan perilaku hidup bersih. Tim Pengabdian Kepada Masyarakat (PKM) dari Universitas Papua memberikan kegiatan penyuluhan kesehatan dan perilaku hidup bersih kepada anak-anak Sekolah Dasar dan para orang tua dengan menargetkan dua desa yaitu Desa Sidey Makmur dan Desa Kaironi di Distrik Sidey, Manokwari, Papua Barat. Tim PKM merancang dan menggunakan bahan kampanye berbasis gambar seperti poster, flipchart dan film pendek selama kegiatan PKM. Tim PKM melihat pesan yang disampaikan menggunakan media berbasis gambar dan bersifat audiovisual dapat dipahami dengan muda oleh semua peserta dari berbagai latar belakang pendidikan, gender, dan usia. Pendidikan kesehatan berbasis gambar efektif untuk meningkatkan kualitas kesehatan masyarakat pedesaan di Papua Barat.

Kata kunci: STH, kecacingan bersumber tanah, perilaku kesehatan, pendidikan kesehatan, pendidikan kesehatan berbasis gambar

\section{PENDAHULUAN}

Indonesia merupakan salah satu negara endemik infeksi cacing gastrointestinal yang dapat ditularkan melalui tanah (Soil-Transmitted Helminthiasis atau disingkat STH) dengan jumlah anak usia 1-14 tahun terbanyak ketiga di dunia setelah India, dan Nigeria yaitu sekitar 7\% (WHO, 2012). Walaupun studi epidemiologi kecacingan di wilayah Papua sangat terbatas, beberapa sumber menyatakan bahwa prevalensi infeksi STH di wilayah ini cukup tinggi. Sebuah studi di Sekolah Dasar (SD) di Abe Pantai, Kota Jayapura melaporkan prevalensi STH mencapai 50\% (Martila, Sandy, \& Paembonan, 2016). Sedangkan penelitian lain melaporkan prevalensi STH di sebuah SD Negeri di Misool Selatan, Kabupaten Raja Ampat sebesar 75\% (Kusmiati, 2015).

Infeksi STH masih merupakan endemik di banyak daerah di dunia, terutama di negara yang sedang berkembang dengan sanitasi lingkungan dan kebersihan diri yang sangat kurang (De Silva et al., 2003; Gordon \& Mcmanus, 2017; Pullan et al., 2011). Selain itu, interaksi yang cukup tinggi antara manusia dengan hewan domestik seperti babi, anjing, dan kucing merupakan faktor predisposisi penularan beberapa spesies cacing STH (Aung et al., 2017; Bradbury, Hii, Harrington, Speare, \& Traub, 2017; CDC, 2018; Leles, Gardner, Reinhard, Ĩiguez, \& Araujo, 2012; Nejsum, 
Betson, Bendall, Thamsborg, \& Stothard, 2012). Oleh karena itu, pencegahan infeksi kecacingan dapat dilakukan dengan cara memberikan promosi kesehatan yang pesannya dapat ditangkap oleh masyarakat dan mengubah perilaku hidup sehat di masyarakat.

Target utama dalam kegiatan pendidikan kesehatan ini adalah anak-anak dan orang tua. Pendidikan kesehatan pada anak usia sekolah terbukti efektif untuk mengingkatkan kesadaran akan pencegahan penyakit-penyakit infeksius (Deray et al., 2018; Lapiz et al., 2012). Pendidikan kesehatan pada orang tua juga sangat penting sebab mereka berperan dalam mengubah perilaku hidup sehat pada anak-anak mereka, sebab orang tua mempunyai kendali untuk menjaga anakanak mereka agar disiplin dalam menerapkan perilaku hidup sehat di keseharian mereka (Tinsley, Markey, Ericksen, \& Ortiz, 2002).

Upaya meningkatkan kesadaran masyarakat merupakan langkah awal yang diperlukan untuk menginisiasi kegiatan ini. Kegiatan pendidikan kesehatan yang bersifat sesuai dengan kearifan lokal dan kebudayaan setempat, mudah dipahami, dan menarik untuk dilihat/didengarkan sangat diperlukan (Henderson, Kendall, \& See, 2011). Dalam kegiatan sosialisasi, informasi yang penting untuk disampaikan adalah jalur transmisi infeksi cacing, dampak yang diakibatkan oleh infeksi cacing, sanitasi personal sebagai upaya pencegahan STH, dan pentingnya pengobatan cacing pada hewan pelihara dan manusia.

Pemutaran video singkat berdurasi 10-15 menit pada kegiatan sosialisasi dipercaya dapat membantu meningkatkan literasi kesehatan dan kesadaran masyarakat terhadap isu-isu kesehatan yang terjadi di masyarakat (Borrayo, 2004). Selain itu, pemutaran animasi bergambar juga terbukti lebih efektif untuk menyampaikan pendidikan kesehatan pada kalangan masyarakat dengan tingkat literasi rendah jika dibandingkan dengan pendidikan kesehatan melalui pesan dan instruksi tertulis (Borrayo, 2004). Penyuluhan kesehatan menggunakan video singkat serta materi yang sarat mengandung gambar sangatlah tepat untuk meningkatkan kesadaran kesehatan di masyarakat dan anak-anak.

Mengingat tingginya prevalensi STH di wilayah Papua yang sangat tinggi, terutama pada anak-anak sekolah dasar, serta pola hidup dimana anak-anak berinteraksi sangat dekat dengan hewan, maka tim Pengabdian Kepada Masyarakat (PKM) melakukan program penyuluhan kesehatan yang bertujuan untuk meningkatkan kesadaran masyarakat akan pentingnya mencegah kecacingan akibat STH sangatlah diperlukan. Program ini diadakan Distrik Sidey, Kabupaten Manokwari, Provinsi Papua Barat karena wilayah ini digolongkan sebagai Kawasan Perdesaan Prioritas Nasional (KPPN) oleh Kementerian Perekonomian dan Pembangunan.

\section{METODE}

Kegiatan PKM ini bertujuan untuk meningkatkan pengetahuan dan kesadaran masyarakat di Distrik Sidey, khususnya di Desa Kaironi dan Desa Sidey Makmur, tentang upaya pencegahan infeksi STH. Target peserta dalam kegiatan ini adalah orang tua dan anak-anak. Kegiatan ini berdurasi selama 8 bulan.

Tahapan kegiatan PKM adalah sebagai berikut.

a. Tim pengabdian melakukan survey lokasi pada bulan Maret 2019 untuk menyampaikan maksud kegiatan kepada Puskesmas Distrik Sidey, Kepala Kampung Desa Kaironi, Kepala Kampung Desa Sidey Makmur, Kepala Sekolah SD Inpres 53 Kaironi, dan Kepala Sekolah SD Inpres 73 Sidey. Pada survey ini, tim PKM juga mendata jumlah anak-anak dan orang tua yang ada di desa target, serta waktu terbaik untuk melaksanakan kegiatan PKM.

b. Persiapan kegiatan mencakup proses pembuatan poster, flip chart, dan video pendek menggunakan Bahasa Papua Melayu dan pesan yang dibuat sederhana dan menggunakan gambar-gambar yang mudah dipahami. Dalam pembuatan video pendek, karakter yang dipilih adalah anak-anak asli Papua, menggunakan setting tempat dan cerita yang sesuai dengan kehidupan masyarakat sehari-hari di Papua. Persiapan peralatan dan 
perlengkapan yang diperlukan selama kegiatan PKM dilakukan seminggu sebelum kegiatan dilaksanakan. Persiapan kegiatan dilakukan pada bulan April-Juli 2019.

c. Kegiatan penyuluhan kesehatan kepada anak-anak dilakukan sebanyak dua kali yaitu pada bulan Agustus dan September 2019. Kegiatan penyuluhan kesehatan kepada orang tua dilakukan sebanyak satu kali pada bulan September 2019.

d. Evaluasi kegiatan dilakukan pada bulan Oktober 2019.

Materi yang dipakai selama kegiatan promosi kesehatan adalah materi cetak berupa poster dan flip chart serta materi audio visual berupa video-video pendek. Hampir seluruh materi dikembangkan dan disusun sendiri oleh tim PKM mengacu kepada bahan promosi kesehatan yang dibuat oleh Kementerian Kesehatan. Selain itu, terdapat dua video pendek lainnya yang diunduh dari YouTube ${ }^{\circledR}$.

Poster berisi pesan tentang cara penularan cacing STH yang umum terjadi di dalam konteks kehidupan sehari-hari dan upaya yang dapat dilakukan untuk mencegahnya. Poster dibuat menggunakan karakter animasi dengan menggunakan karakter anak-anak asli Papua dan anak-anak non-Papua. Tulisan yang dicetak pada poster menggunakan Bahasa Papua Melayu yang ditulis dengan singkat untuk menerangkan setiap gambar yang ada dalam poster. Pemilihan warna menggunakan warna-warna terang yang disukai anak-anak.

Flip chart berisi pesan tentang indikator Pola Hidup Bersih dan Sehat (PHBS) di sekolah dan di rumah tangga. Flip chart ini disusun dengan mengacu kepada materi yang disusun oleh Kementerian Kesehatan. Namun flip chart yang tim PKM gunakan dimodifikasi menggunakan gambar-gambar dari anak-anak asli Papua dan anak-anak non-Papua serta menggunakan Bahasa Papua Melayu. Ada dua flip chart yang digunakan untuk kegiatan ini.

Video yang digunakan dalam kegiatan ini sebanyak 4 buah. Terdapat dua video menggunakan kartun animasi yang diunduh dari YouTube ${ }^{\circledR}$. Video ini menceritakan tentang pentingnya mencuci tangan menggunakan sabun (CTPS) dan PHBS di sekolah. Selain itu, Tim PKM juga membuat dua buah video pendek berdurasi 3-5 menit dengan menggunakan karakter dari anak-anak asli Papua. dalam video ini diceritakan tentang pentingnya Higiene Personal dan tentang pentingnya menggunakan alas kaki dan CTPS untuk mencegah STH dan penyakit infeksius lainnya. Di dalam video ini, Bahasa yang digunakan adalah Bahasa Papua Melayu serta menggunakan setting lokasi rumah penduduk di daerah pesisir pantai.

Kegiatan penyuluhan kesehatan di sekolah dilakukan sebanyak dua kali. Pada kegiatan pertama, anak-anak diajarkan tentang pentingnya mencuci tangan pakai sabun (CTPS) melalui video animasi dan menggunakan demonstrasi. Pada saat demonstrasi, anak-anak dibagi menjadi dua kelompok; kelompok pertama adalah pasukan tangan bersih dan kelompok kedua adalah pasukan tangan kotor. Anak-anak yang tergabung dalam pasukan tangan kotor seluruh bagian telapak dan punggung tangannya dilumuri dengan minyak bayi (baby oil) dan glitter berwarna.

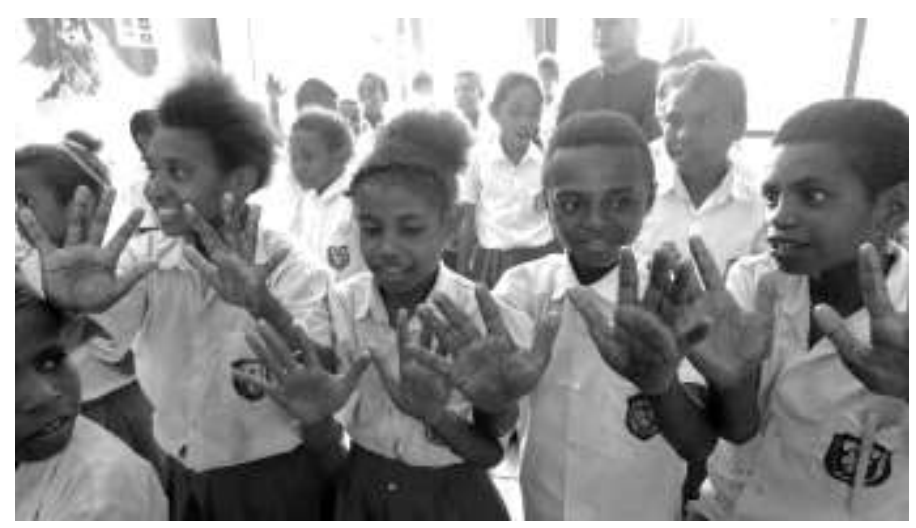

Gambar 1. Demonstrasi pentingnya CTPS di SD Inpres 53 Kaironi; pasukan tangan kotor berfoto sebelum bermain dengan teman-temannya dari pasukan tangan bersih. (sumber: dokumentasi tim PKM) 
Kemudian kedua kelompok ini diminta untuk bermain bola bersama-sama sambil menyentuh tangan teman-temannya. Setelah bermain, anak-anak diberi penjelasan bahwa glitter diumpamakan sebagai kuman penyakit (bakteri/telur cacing/atau virus) yang dapat berpindah ketika mereka berkontak fisik dengan teman-temannya. Setelah itu, anak-anak diajarkan cara mencuci tangan menggunakan air bersih dan sabun. Pada kegiatan kedua, anak-anak diajarkan tentang cara mencegah penyakit STH menggunakan tiga media, yaitu poster, flip chart, dan dua buah video yang dibuat oleh tim PKM.

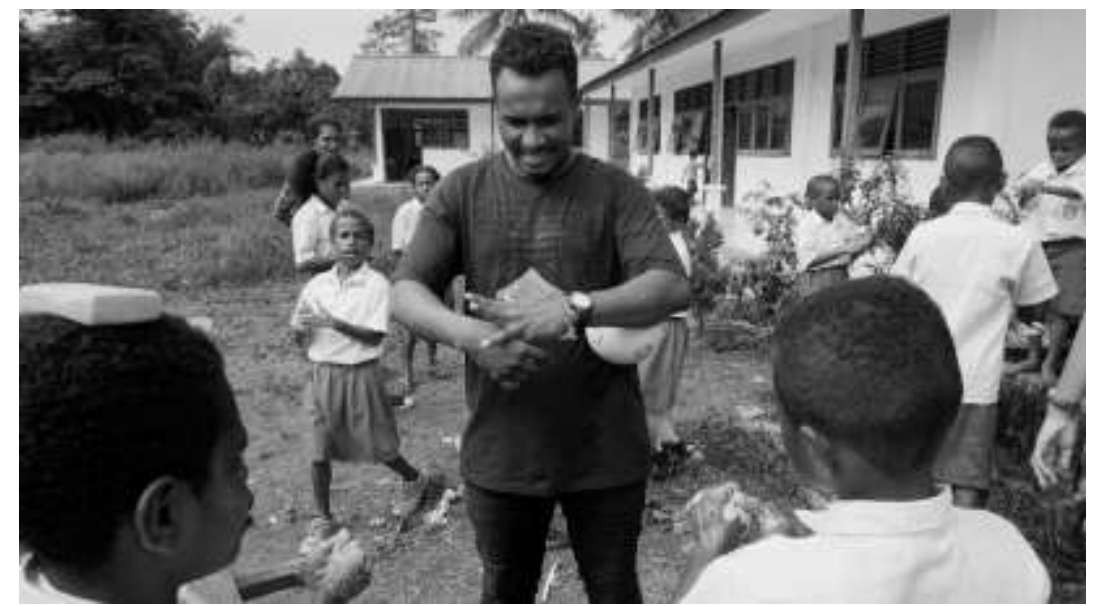

Gambar 2. Anggota tim PKM sedang memberikan contoh cara CTPS yang benar (sumber: dokumentasi tim PKM)

Kegiatan penyuluhan kesehatan untuk orang tua di setiap desa masing-masing dilakukan sebanyak satu kali bertempat di Balai Desa Kaironi dan Balai Desa Sidey Makmur. Pada kegiatan ini, Tim PKM memberikan ceramah menggunakan poster pencegahan cacingan dan flip chart tentang PHBS Rumah Tangga.

\section{HASIL DAN PEMBAHASAN}

Kepala Puskesmas Distrik Sidey menyambut kegiatan ini dengan baik. Berdasarkan keterangan dari pembicaraan dengan beliau saat survey, beliau mengatakan bahwa petugas kesehatan mengalami kesulitan untuk memberikan obat cacing rutin kepada seluruh anak-anak di sekolah sebab ketika pelaksanaan pemberian obat cacing di sekolah-sekolah, ada beberapa anak yang tidak masuk sekolah sebab mereka harus membantu orang tuanya bekerja di ladang. Meskipun pihak sekolah sudah mengingatkan kepada para siswa untuk hadir sekolah pada saat yang sudah ditentukan oleh Puskesmas, masih ada anak yang tidak masuk sekolah. Oleh karena itu, pemberian edukasi kesehatan tentang pentingnya pemberian obat cacing yang rutin sebagai salah satu upaya pencegahan sangat perlu untuk disampaikan.

Pada saat penyuluhan menggunakan poster, seluruh peserta diminta untuk menebak informasi yang terdapat pada gambar. Sebagian besar peserta, baik anak maupun orang tua, dapat memahami gambar yang diberikan meskipun mereka tidak membaca tulisan yang ada di bawah gambar. Anak-anak dapat menyebutkan jalur penularan cacing STH dan upaya pencegahannya hanya dengan melihat gambar yang terdapat pada poster.

Pada saat penyuluhan menggunakan flip chart, seluruh peserta juga diminta untuk menebak informasi yang terdapat pada gambar. Respon mereka juga sama dengan ketika mereka melihat poster. Sebagian besar dari mereka mampu memahami gambar yang ditunjukkan tanpa membaca tulisan yang terdapat di bagian bawah gambar. Baik anak-anak maupun orang tua mampu menyebutkan PHBS di sekolah dan rumah tangga hanya dengan melihat gambar. 
Pada saat video pendek diputar, seluruh anak-anak memperhatikan dengan baik. Video berdurasi pendek, menggunakan tokoh animasi dan tokoh anak-anak asli Papua, serta menggunakan hahasa sehari-hari mampu membuat anak-anak memahami pesan yang disampaikan melalui video tersebut. Hal ini diukur dengan memberikan pertanyaan lisan yang terkait informasi yang diberikan oleh video. Hampir semua anak mampu menjawab secara lisan pertanyaan yang diberikan oleh tim PKM terkait informasi dari video tersebut.
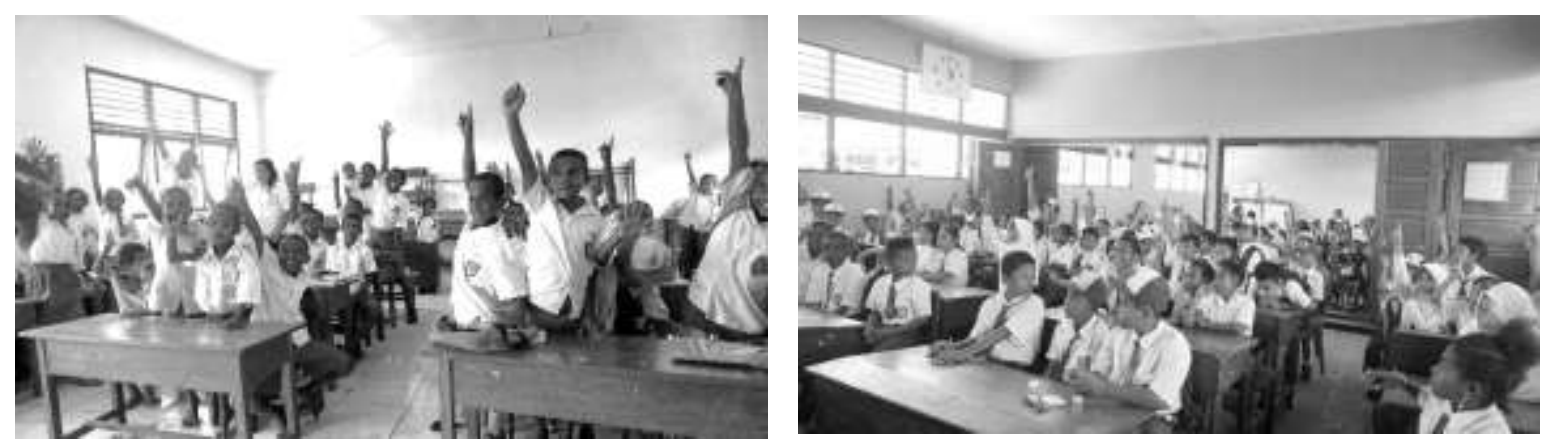

Gambar 3. Anak-anak di Distrik Sidey menjawab pertanyaan lisan dengan antusias (a) SD Inpres 53 Kaironi (b) SD Inpres 73 Sidey Makmur (sumber: dokumentasi tim PKM)

Seorang guru dari SD Inpres 53 Kaironi menyatakan bahwa masih ada anak-anak yang defekasi di tempat terbuka, terkadang karena fasilitas air yang kurang tetapi juga karena sudah menjadi kebiasaan bagi beberapa anak. Beliau menyatakan bahwa penyuluhan kesehatan ini penting untuk mengubah kesadaran anak-anak bahwa perilaku buang air di tempat terbuka dapat menjadi sumber penularan kecacingan.

Secara umum, tim PKM melihat bahwa penyuluhan kesehatan ini efektif untuk menambah pengetahuan anak-anak dan orang tua terkait STH. Peserta, terutama anak-anak, sangat antusias mengikuti penyuluhan kesehatan sebab sepanjang kegiatan anak-anak melihat gambar dan video yang menarik. Selain itu, pesan juga disampaikan sambil mengajak anak-anak bermain bola.

Mengubah informasi sains tentang cara transmisi STH dan upaya pencegahan STH ke dalam pesan sederhana yang mampu meningkatkan pengetahuan dan kesadaran masyarakat merupakan hal yang paling menantang dari keseluruhan kegiatan ini. Dari keseluruhan media cetak dan media audiovisual yang digunakan selama kegiatan, video pendek merupakan media yang mampu membuat peserta memberikan perhatian penuh terhadap pesan yang disampaikan. Poster dan flip chart bergambar merupakan media paling sederhana dan mampu membuat peserta memahami pesan yang ada di dalam gambar tersebut meskipun peserta tidak mampu membaca pesan teks/tertulis.

Berdasarkan hasil kegiatan ini, tim PKM merekomendasikan agar penyuluhan kesehatan di daerah pedesaan menggunakan materi-materi cetak yang tidak sarat dengan tulisan, melainkan menggunakan gambar yang mudah dimengerti oleh pembaca dari segala umur. Tim PKM juga merekomendasikan penggunaan pesan teks/audio menggunakan bahasa sehari-hari yang dipakai oleh peserta yang menjadi target penyuluhan. Video seperti cerita pendek yang menggunakan ide cerita yang sesuai dengan kehidupan sehari-hari masyarakat pada umumnya, menggunakan karakter asli penduduk setempat, serta menggunakan setting lokasi yang dekat dengan kehidupan masyarakat juga sangat diperlukan agar penonton dapat merefleksikan bahwa cerita/kejadian yang ada di video juga dapat terjadi dalam kehidupan mereka. Sebuah penelitian di Burkina Faso menyatakan bahwa video promosi kesehatan yang dibuat menggunakan bahasa lokal yang hanya dimengerti oleh komunitas setempat berpotensi menjadi video yang viral yang disebarkan di dalam komunitas tersebut (Swigart et al., 2019). Di Indonesia sendiri, pendidikan kesehatan menggunakan video juga dipraktekkan oleh beberapa komunitas, diantaranya sebagai 
edukasi anti narkoba (Mustafa et al., 2020) dan pencegahan anti pelecehan seksual (Djannah et al., 2020).

Namun demikian, kegiatan PKM ini masih memiliki kelemahan terutama dalam hal evaluasi kegiatan. Tim PKM tidak melakukan pengujian kuantitatif untuk mengukur tingkat pengetahuan, sikap, dan perilaku masyarakat sebelum dan setelah kegiatan ini sehingga efektivitas penyuluhan ini masih belum dapat diukur secara kuantitatif. Materi yang dibuat dalam kegiatan PKM ini dapat dipergunakan untuk mengukur apakah efektif untuk digunakan sebagai kampanye untuk mencegah kecacingan pada masyarakat Papua secara luas.

Agar kegiatan serupa dapat berjalan secara berkelanjutan dan lebih luas, tim PKM menyarankan agar penyuluhan kesehatan di sekolah diintegrasikan dengan kurikulum sekolah, misalnya pada pelajaran sains. Dinas Kesehatan setempat dapat mengadakan pelatihan kepada guru-guru sekolah untuk mengadakan kegiatan ini bersama siswa-siswa mereka di sekolah masing-masing. Selain poster, flip chart, dan video yang sudah dibuat oleh Tim PKM, juga diperlukan sebuah buku panduan berupa aktivitas dan peralatan sederhana yang diperlukan dalam kegiatan penyuluhan kesehatan ini. Mengintegrasikan edukasi kesehatan ke dalam kurikulum sekolah sudah dilakukan di Filipina sebagai strategi yang efektif untuk mencegah rabies pada anak-anak usia sekolah (Lapiz et al., 2012).

\section{KESIMPULAN}

Selain pemberian obat cacing rutin yang sudah dilakukan oleh pemerintah, penyuluhan kesehatan sangat diperlukan untuk mencegah infeksi cacing STH. Penyuluhan kesehatan kepada anak-anak usia sekolah dapat diberikan pada saat jam belajar atau diberikan dengan mengintegrasikan kurikulum yang ada di sekolah sehingga tidak mengganggu proses belajar mengajar.

Media cetak berisi gambar yang dapat dimengerti dan menarik serta menggunakan pesan teks bahasa setempat sangat perlu agar pesan dapat dimengerti oleh target audiens dari berbagai latar belakang pendidikan dan usia. Media audio visual berupa video singkat yang menggunakan bahasa setempat juga dapat dipergunakan sebagai sarana penyampai pesan yang efektif.

\section{UCAPAN TERIMA KASIH}

Tim PKM mengucapkan terima kasih kepada DRPM DIKTI atas pendanaan kegiatan PKM 2019 di Universitas Papua.

\section{DAFTAR PUSTAKA}

Aung, W. P. P., Htoon, T. T., Tin, H. H., Sanpool, O., Jongthawin, J., Sadaow, L., ... Maleewong, W. (2017). First molecular identifications of necator americanus and ancylostoma ceylanicum infecting rural communities in lower Myanmar. American Journal of Tropical Medicine and Hygiene, 96(1), 214-216. https://doi.org/10.4269/ajtmh.16-0610

Borrayo, E. (2004). Where's Maria? A video to increase awareness about breast cancer and mammography screening among low-literacy Latinas. Preventive Medicine, 39(1), 99-110.

Bradbury, R. S., Hii, S. F., Harrington, H., Speare, R., \& Traub, R. (2017). Hookworm in the Solomon Islands, 23(2).

CDC. (2018). Parasites-Ascariasis. Retrieved November 15, 2019, from https://www.cdc.gov/parasites/ascariasis/

De Silva, N. R., Brooker, S., Hotez, P. J., Montresor, A., Engels, D., \& Savioli, L. (2003). Soiltransmitted helminth infections: Updating the global picture. Trends in Parasitology, 19(12), 547-551. https://doi.org/10.1016/j.pt.2003.10.002

Deray, R., Rivera, C., Gripon, S., Ulanday, C., Roces, M. C., Amparo, A. C., ... Miranda, M. E. (2018). 
Protecting children from rabies with education and pre-exposure prophylaxis: A school-based campaign in El Nido, Palawan, Philippines. PLoS ONE, 13(1), 1-18. https://doi.org/10.1371/journal.pone.0189596

Djannah, S. N., Djannah, S. N., Mulasari, S. A., Sulistyawati, S., Sukesi, T. W., \& Tentama, F. (2020). PKM Desa Wisata Sehat: Outbound dan Edukasi Kesehatan. Dinamisia: Jurnal Pengabdian Kepada Masyarakat, 3(2), 252-257. https://doi.org/10.31849/dinamisia.v3i2.3180

Gordon, C. A., \& Mcmanus, D. P. (2017). Soil-Transmitted Helminths in Tropical Australia and Asia. https://doi.org/10.3390/tropicalmed2040056

Henderson, S., Kendall, E., \& See, L. (2011). The effectiveness of culturally appropriate interventions to manage or prevent chronic disease in culturally and linguistically diverse communities: A systematic literature review. Health and Social Care in the Community, 19(3), 225-249. https://doi.org/10.1111/j.1365-2524.2010.00972.x

Kusmiati, M. (2015). Prevalensi Infeksi Nematoda Usus pada Anak-anak di SDN 10 Fafanlap, Misool Selatan, Raja Ampat, Papua Barat. Universitas Gajah Mada.

Lapiz, S. M. D., Miranda, M. E. G., Garcia, R. G., Daguro, L. I., Paman, M. D., Madrinan, F. P., ... Briggs, D. J. (2012). Implementation of an Intersectoral Program to Eliminate Human and Canine Rabies: The Bohol Rabies Prevention and Elimination Project. PLoS Neglected Tropical Diseases, 6(12). https://doi.org/10.1371/journal.pntd.0001891

Leles, D., Gardner, S. L., Reinhard, K., Ĩiguez, A., \& Araujo, A. (2012). Are Ascaris lumbricoides and Ascaris suum a single species? Parasites and Vectors, 5(1), 1-7. https://doi.org/10.1186/1756-3305-5-42

Martila, M., Sandy, S., \& Paembonan, N. (2016). Hubungan Higiene Perorangan dengan Kejadian Kecacingan pada Murid SD Negeri Abe Pantai Jayapura. JURNAL PLASMA, 1(2). https://doi.org/10.22435/plasma.v1i2.4538.87-96

Mustafa, I. R., Abdillah, M. B., Winata, N. R., Pratama, R., Rosi Isnanda, Putra, T. D. A., \& Sulistyo, W. D. (2020). Edukasi Gerakan Siswa Anti Narkoba" (Geswana) Era Desrupsi 4.0 di Smp Wahid Hasyim Malang. Dinamisia: Jurnal Pengabdian Kepada Masyarakat, 3(2), 189-197. https://doi.org/10.31849/dinamisia.v3i2.3214

Nejsum, P., Betson, M., Bendall, R. P., Thamsborg, S. M., \& Stothard, J. R. (2012). Assessing the zoonotic potential of Ascaris suum and Trichuris suis : looking to the future from an analysis of the past. Journal of Helminthology, 86(2), 148-155. https://doi.org/10.1017/S0022149X12000193

Pullan, R. L., Gething, P. W., Smith, J. L., Mwandawiro, C. S., Sturrock, H. J. W., Gitonga, C. W., ... Brooker, S. (2011). Spatial modelling of soil-transmitted helminth infections in Kenya: A disease control planning tool. PLoS Neglected Tropical Diseases, 5(2). https://doi.org/10.1371/journal.pntd.0000958

Swigart, T., Hollowell, J., Remes, P., Lavoie, M., Murray, J., Belem, M., ... Head, R. (2019). Can health promotion videos 'go viral'? A non-randomised, controlled, before-and-after pilot study to measure the spread and impact of local language mobile videos in Burkina Faso. Global Health Action, 12(1). https://doi.org/10.1080/16549716.2019.1600858

Tinsley, B. J., Markey, C. N., Ericksen, A. J., \& Ortiz, R. V. (2002). Health Promotion for Parents. In Handbook of Parenting: Practical Issues in Parenting (5th ed., pp. 384-328).

WHO. (2012). WHO | Soil-transmitted helminthiases: number of children treated in 2010. WHO. Retrieved November 20, 2019, from https://www.who.int/intestinal_worms/resources/who_wer8723/en/ 